\title{
Case report: a complete heart block as a manifestation of bioprosthetic aortic valve endocarditis
}

\section{(D)Ana Šutalo'”, (DKrešimir Šutalo', (D)Eugen Fucak', DSiniša Štubelj1, (D) Mario Milun', (DDaniel Unić², (DSavica Gjorgjievska²}

'General Hospital “Dr.

Tomislav Bardek", Koprivnica, Croatia

${ }^{2}$ University Hospital Dubrava, Zagreb, Croatia

\begin{abstract}
KEYWORDS: infective endocarditis, atrioventricular block, bioprosthetic aortic valve, aortic root abscess CITATION: Cardiol Croat. 2021;16(5-6):195. | https://doi.org/10.15836/ccar2021.195

*ADDRESS FOR CORRESPONDENCE: Ana Šutalo, Opća bolnica “Dr. Tomislav Bardek" Koprivnica, Ulica doktora Željka Selingera bb, HR-48000 Koprivnica, Croatia. / Phone: +385-99-4023194 / E-mail: anasutalo1989@gmail.com ORCID:Ana Šutalo, https://orcid.org/0000-0002-7644-6362 • Krešimir Šutalo, https://orcid.org/0000-0003-0719-0065 Eugen Fucak, https://orcid.org/0000-0002-4139-2480 • Siniša Štubelj, https://orcid.org/0000-0001-6688-2366 Mario Milun, https://orcid.org/0000-0002-9535-6856 • Daniel Unić, https://orcid.org/0000-0003-2740-4067 Savica Gjorgjievska, https://orcid.org/0000-0002-4304-1852
\end{abstract}

\section{|I|||||||||||||||||||||||||||||||||||||||||||||||||||||||||||||||||||||||||||||||||||||||||||||||||||||||||||||||||||||||||||||}

Introduction: A perivalvular extension of infection is the complication of bacterial endocarditis. Because prosthetic valve endocarditis (PVE) usually begins as periannulitis, it is not surprising that infected prosthetic valves had these complications with a higher frequency than did infected native valves. ${ }^{1}$ In case of an aortic prosthetic valve infective endocarditis (IE), the infection has tendency to extend towards the membranous septum and into the conducting tissue. We present a case of culturenegative IE resulting in a dehiscence of a bioprosthetic aortic valve complicated by aortic root abscess and complete heart block
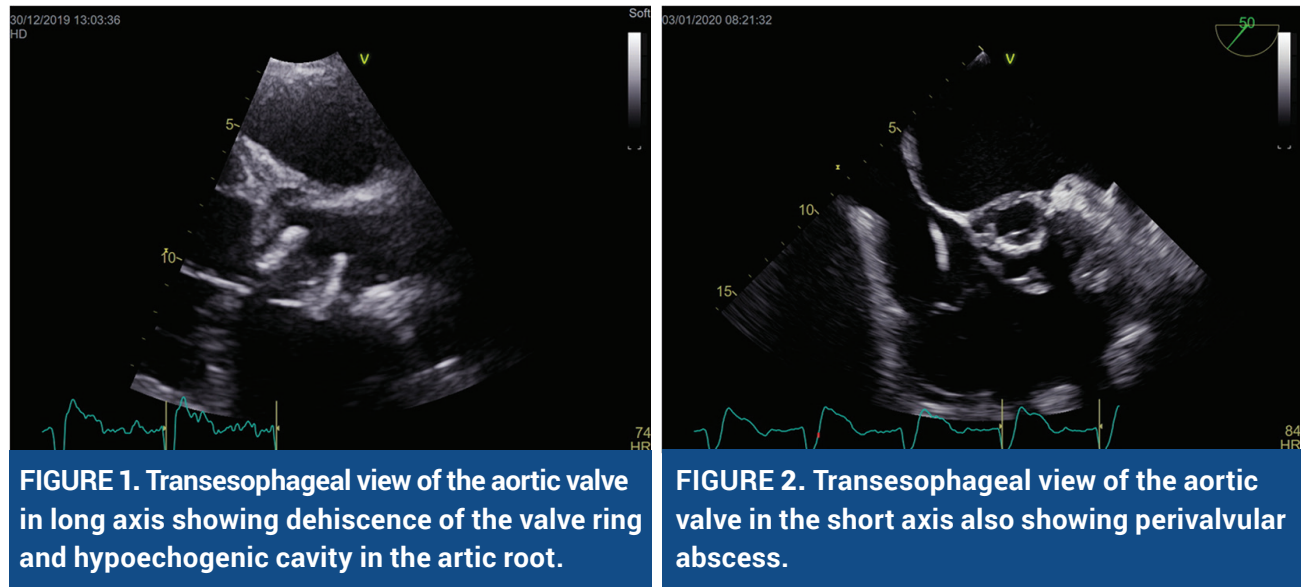

Case report: 67-year-old man, who underwent aortic valve replacement (Medtronic Mosaic A25) for severe aortic valve insufficiency 15 months before, presented to the emergency department with dyspnea and syncopal episodes. Electrocardiogram demonstrated left bundle branch block with intermittent complete heart block causing ventricular pauses up to 15 seconds. An urgent pacemaker implantation was performed. During the consecutive hospital staying he developed fever accompanied by worsening of congestive heart failure. The chest radiography showed suspected pneumonia. The transesophageal echocardiography revealed perivalvular aortic root abscess with partial valve dehiscence and moderate aortic regurgitation (Figure 1, Figure 2). Inflammatory markers were elevated, while blood cultures remained sterile. The empirical antimicrobial treatment for infective endocarditis and pneumonia was initiated. Despite pharmacological measures, the patient's condition was gradually deteriorating so he underwent early cardiac surgery. The prosthetic valve replacement together with pericardial patch reconstruction of annulus was successfully performed.

Conclusion: Culture-negative endocarditis constitutes up to $16 \%$ to $18 \%$ of $\mathrm{PVE},{ }^{2,3}$ and can rarely be complicated by prosthetic aortic valve dehiscence. ${ }^{4}$ The appearance of an AV conduction block can be a sign of underlying aortic root abscess as perivalvular complication of prosthetic aortic valve IE.

March 28, 2021

ACCEPTED:

April 2, 2021

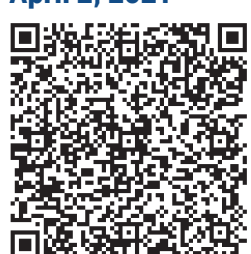

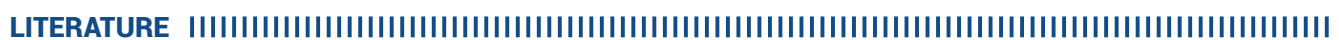

1. Graupner C, Vilacosta I, SanRomán J, Ronderos R, Sarriá C, Fernández C, et al. Periannular extension of infective endocarditis. J Am Coll Cardiol. 2002 Apr 3;39(7):1204-11. https://doi.org/10.1016/S0735-1097(02)01747-3

2. López J, Revilla A, Vilacosta I, Villacorta E, González-Juanatey C, Gómez I, et al. Definition, clinical profile, microbiological spectrum, and prognostic factors of early-onset prosthetic valve endocarditis. Eur Heart J. 2007 Mar;28(6):760-5. https://doi.org/10.1093/eurheartj/ehl486

3. Alonso-Valle H, Fariñas-Alvarez C, García-Palomo JD, Bernal JM, Martín-Durán R, Gutiérrez Díez JF, et al. Clinical course and predictors of death in prosthetic valve endocarditis over a 20-year period. J Thorac Cardiovasc Surg. 2010 Apr;139(4):887-93. https://doi.org/10.1016/j.jtcvs.2009.05.042

4. Klimis H, Altman M, Chard R, Skinner M, Thomas L. Dehiscence of a Mechanical Aortic Valve Secondary to Culture-Negative Endocarditis Complicated by Acute Heart Failure. CASE (Phila). 2019 Jun 1;3(5):215-219. https://doi.org/10.1016/j.case.2019.04.008 